\title{
PENGARUH PERBEDAAN PENGELOLAAN AGROEKOSISTEM TANAMAN TERHADAP STRUKTUR KOMUNITAS SERANGGA PADA PERTANAMAN KEDELAI DI NGALE, KABUPATEN NGAWI, JAWA TIMUR
}

\author{
Lutfi Afifah', Purnama Hidayat ${ }^{2}$, Damayanti Buchori², Marwoto ${ }^{3}$, \& B.T Rahardjo ${ }^{4}$ \\ ${ }^{1}$ Pasca Sarjana Entomologi, Fakultas Pertanian, Institut Pertanian Bogor, Indonesia \\ ${ }^{2}$ Departemen Proteksi Tanaman, Fakultas Pertanian, Institut Pertanian Bogor, Indonesia \\ Jl. Kamper, Kampus IPB Darmaga, Kabupaten Bogor, Provinsi Jawa Barat 16680 \\ ${ }^{3}$ Balai Penelitian Aneka Kacang dan Umbi, Malang, Badan Litbang Pertanian, Departemen Pertanian, RI \\ ${ }^{4}$ Jurusan Hama dan Penyakit Tumbuhan, Fakultas Pertanian, Universitas Brawijaya, Malang, Indonesia \\ E-mail: lutfiafifah@ymail.com
}

\begin{abstract}
Effect of different agroecosystem management on community structure of insects in soybean crop in Ngale, Ngawi District, East Java. Insect community structures in agroecosystem may always change. Agroecosystem management techniques affect insect community structure. The aim of this study was to determine the diversity and composition of insects on soybean plants under different pest management systems and varieties. The experiment design was split plot with varieties (Anjasmoro and Wilis) as the main plots and pest management systems (Integrated Pest Management (IPM), Non-Chemical Management (P-NK), Chemical Management (P-K), and Control) as the sub plots. There were ten insect sampling sessions for each plot. Samplings were done in June until September 2013 using pitfall traps, sticky traps, sweep net, and yellow pan traps. Statistically the results of experiment showed that varieties and pest management had no significant differences to the insects diversity. Herbivore and beneficial insect in soybean crop had differences composition between varieties Anjasmoro and Wilis. In both soybean Anjasmoro and Wilis varieties, herbivore populations tend to be higher in the control plots compared to the IPM plots. Abundance of decomposers, parasitoids, and predators tend to be higher in the control and P-NK plots which were without the use of synthetic insecticides compared to the IPM and P-K plots which were given the treatment of synthetic pesticides. This indicates that the use of pesticides causes decrease in the beneficial insect populations such as pollinator, parasitoids, and predators.
\end{abstract}

Key words: Anjasmoro variety, insect diversity, insect pests, parasitoids, population dynamics, predators, Wilis variety

\begin{abstract}
ABSTRAK
Pengaruh perbedaan pengelolaan agroekosistem tanaman terhadap struktur komunitas serangga pada pertanaman kedelai di Ngale, Kabupaten Ngawi, Jawa Timur. Struktur komunitas serangga di agroekosistem selalu berubah. Pengelolaan agroekosistem pertanian mempengaruhi struktur komunitas serangga. Penelitian ini bertujuan untuk mengetahui keanekaragaman dan komposisi serangga pada tanaman kedelai dengan pengelolaan hama dan varietas yang berbeda. Rancangan percobaan yang digunakan adalah rancangan petak terbagi RAK dengan petak utama varietas (Anjasmoro dan Wilis) dan pengelolaan hama sebagai anak petak. Pengelolaan hama meliputi Pengelolaan Hama Terpadu (PHT), Pengendalian Non-Kimiawi (P-NK), Pengendalian Kimiawi (P-K), dan Kontrol. Terdapat sepuluh kali sampling serangga pada masingmasing petak dalam satu musim tanam. Pengambilan sampel serangga pada bulan Juni sampai September 2013 dengan menggunakan perangkap lubang jebakan, jaring serangga, perangkap nampan kuning, dan perangkap berperekat. Hasil penelitian menunjukkan bahwa perlakuan varietas dan pengelolaan hama tidak berpengaruh signifikan terhadap indeks keanekaragaman serangga. Komposisi serangga herbivora dan serangga bermanfaat di pertanaman kedelai memiliki perbedaan komposisi spesies antara varietas Anjasmoro dan Wilis. Pada kedua varietas kedelai populasi herbivora cenderung lebih tinggi pada petak Kontrol dibandingkan dengan petak PHT. Kelimpahan populasi serangga pengurai, parasitoid, dan predator cenderung lebih tinggi pada petak Kontrol dan P-NK yang tanpa menggunakan insektisida sintetis dibandingkan dengan petak PHT dan P-K yang mendapatkan perlakuan pestisida sintetis. Hal ini menunjukkan bahwa penggunaan pestisida dapat menyebabkan penurunan populasi serangga bermanfaat seperti penyerbuk, parasitoid, dan predator.
\end{abstract}

Kata kunci: dinamika populasi, keanekaragaman serangga, parasitoid, predator, serangga hama, varietas Anjasmoro, varietas Wilis 


\section{PENDAHULUAN}

Struktur komunitas serangga di ekosistem selalu berubah begitu juga komponen yang berhubungan dengan jaring-jaring makanan. Interaksi antara komponen biotik dan abiotik di ekosistem akan mempengaruhi mortalitas, natalitas, penyebaran serangga pada ekosistem, sehingga komposisi spesies selalu dinamis. Intervensi manusia dalam sistem budidaya pertanian jika tidak dilakukan secara benar akan menimbulkan masalah. Pada banyak kasus, penggunaan pestisida yang dimaksudkan untuk mengurangi dampak kehilangan produksi akan mengakibatkan perubahan lingkungan yang tidak diinginkan (Altieri \& Nicholls, 2004).

Di Indonesia, sampai saat ini penelitian mengenai tanaman kedelai dari sisi ekologis masih sedikit. Strategi pengendalian hama pada tanaman kedelai mulai tahun 1980-an menggunakan varietas resisten dan juga penggunaan insektisida secara intensif. Saat ini upaya pengendalian hama dilakukan secara bijak berdasarkan pada sistem pengelolaan hama terpadu (PHT). PHT merupakan suatu cara pengelolaan organisme pengganggu tanaman (OPT) berdasarkan pertimbangan ekologi dan efisiensi ekonomi dalam rangka pengelolaan ekosistem yang berwawasan lingkungan dan berkelanjutan. Sistem PHT ini lebih menonjolkan keterpaduan penggunaan beberapa komponen seperti: tanaman sehat, penggunaan varietas ungul (Tahir et al., 2011), Plant Growth Promoting Rhizobacteria (PGPR), peningkatan peran musuh alami, pengendalian secara fisik dan mekanik, insektisida botanis (Baliadi \& Tengkano, 2010), agens hayati (Arifin, 2012), tanaman pinggir (Tillman, 2014), dan insektisida sintetik jika diperlukan.

Beberapa varietas kedelai yang sering ditanam oleh petani kedelai, dua diantaranya adalah varietas Wilis dan Anjasmoro. Varietas Wilis merupakan varietas unggul yang telah dilepas sejak 1983 dan telah ditanam pada berbagai tipe lahan sedangkan varietas Anjasmoro merupakan varietas unggul baru yang memiliki produktivitas tinggi (Ghulamahdi et al., 2009). Karakteristik varietas Anjasmoro dan Wilis berbeda antara lain warna daun, warna bulu, ukuran polong, warna polong, tinggi tanaman, umur berbunga, umur masak polong, ketahanan terhadap penyakit dll. Perbedaan karakteristik dari kedua varietas tersebut diduga berpengaruh terhadap struktur komunitas serangga di dalamnya.

Penelitian mengenai efek insektisida terhadap komunitas Artropoda pada tanaman padi pernah dilakukan oleh Settle et al. (1996). Penelitian mengenai efek penggunaan pestisida pada struktur komunitas Artropoda pada tanaman kedelai sudah dilakukan di Australia oleh Ristyadi (2011). Penelitian struktur komunitas serangga pada tanaman kedelai sangat penting, karena pengetahuan tentang kompleksitas proses interaksi tingkat tropik yang terjadi di alam dapat membantu untuk menyusun strategi pengelolaan serangga hama yang lebih baik. Penelitian ini bertujuan untuk mengetahui (1) keanekaragaman dan komposisi spesies serangga pada tanaman kedelai; (2) peranan fungsional dan profil komunitas serangga pada tanaman kedelai dengan pengelolaan hama dan varietas yang berbeda.

\section{METODE PENELITIAN}

Tempat dan Waktu. Penelitian dilaksanakan di kebun percobaan milik Balai Tanaman Kacang-kacangan dan Umbi-umbian (BALITKABI) unit kebun Desa Ngale, Kabupaten Ngawi, Jawa Timur. Identifikasi serangga dilaksanakan di Laboratorium Taksonomi dan Biosistematika Departemen Proteksi Tanaman IPB dan di Laboratorium Entomologi, Bidang Zoologi Puslit Biologi-LIPI Cibinong, Bogor. Pelaksanaan percobaan yaitu pada musim tanam ke-2 (MK II) setelah panen padi, yaitu bulan Juni 2013 sampai dengan September 2013 dilanjutkan identifikasi di laboratorium pada bulan Oktober 2013 sampai dengan Mei 2014.

Pengelolaan Hama pada Kedelai. Dalam penelitian ini digunakan dua varietas kedelai yaitu Anjasmoro dan Wilis. Masing-masing varietas ditanam dengan menggunakan tiga perlakuan pengelolaan hama yang berbeda dan satu kontrol. Pengelolaan hama tersebut adalah: Pengelolaan Hama Terpadu (PHT), Pengendalian Non-Kimiawi (P-NK), Pengendalian Kimiawi (P-K), dan Kontrol. Pada petak PHT digunakan perlakuan plant growth promoting rhizobacteria (PGPR), penggunaan border tanaman jagung, biopestisida mimba, dan pestisida sintetik. Pada P-NK adalah perlakuan PGPR, penggunaan biopestisida Spodoptera litura nucleopolyhedrovirus (SlNPV), dan biopestisida mimba. Pada P-K hanya dilakukan pengendalian dengan pestisida sintetik terjadwal sebanyak enam kali/musim tanam, sedangkan pada petak kontrol tidak dilakukan pengendalian hama apapun. Masing-masing petak perlakuan diulang sebanyak tiga kali. Penempatan perlakuan berdasarkan rancangan petak terbagi RAK dengan petak utama yaitu varietas dan anak petak yaitu pengelolaan hama. Satu petak percobaan berukuran $10 \times 10 \mathrm{~m}$. Total semua petak percobaan adalah 24 petak. 
Pengumpulan Data Keanekaragaman Serangga Koleksi Serangga Menggunakan Perangkap Lubang Jebakan. Perangkap lubang jebakan (pitfall trap) terbuat dari gelas plastik volume $\pm 240 \mathrm{ml}$, berdiameter $7 \mathrm{~cm}$, dengan kedalaman lubang (tinggi gelas) $10 \mathrm{~cm}$. Gelas tersebut diisi dengan larutan sabun kira-kira sampai seperempat volumenya. Pemasangan perangkap dimulai sesudah 1 MST (minggu setelah tanam) dan diulang setiap minggu hingga 10 MST. Perangkap dikumpulkan setelah dipasang 2 x 24 jam di lapangan. Banyaknya perangkap adalah lima buah dan dipasang pada setiap pengamatan secara diagonal.

Koleksi Serangga Menggunakan Nampan Kuning. Nampan kuning terbuat dari wadah plastik berukuran alas 15 x $25 \mathrm{~cm}$ dan tinggi $7 \mathrm{~cm}$. Nampan kuning berisi larutan sabun dipasang pada tiga titik pada masingmasing petak percobaan. Nampan kuning dipasang di tempat yang agak terbuka sehingga mudah terlihat oleh serangga. Pada setiap petak dipasang tiga nampan dan dibiarkan selama 24 jam. Pengamatan serangga dengan nampan kuning dimulai setelah 1 MST dan diulang tiap minggunya sampai $10 \mathrm{MST}$.

Koleksi Serangga Menggunakan Perangkap
Berperekat dan Jaring Serangga. Perangkap berperekat terbuat dari karton plastik bewarna kuning dan berukuran $25 \times 10 \mathrm{~cm}^{2}$. Pada setiap plot dipasang tiga perangkap berperekat dan dibiarkan selama 3 × 24 jam. Pengamatan serangga menggunakan perangkap berperekat ini dimulai 3 MST sampai 10 MST. Selain itu juga digunakan jaring serangga berukuran diameter $37,5 \mathrm{~cm}$. Serangga dikoleksi dengan cara mengayunkan jaring sebanyak lima kali pada baris dan diulang sebanyak lima kali. Pengamatan serangga dengan jaring serangga dimulai setelah 1 MST dan diulang tiap minggunya sampai 10 MST.

Identifikasi Serangga. Penanganan spesimen diawali dengan sortasi. Setiap spesimen diberi label yang memuat informasi jenis morfospesies. Identifikasi mengacu pada buku identifikasi (CSIRO, 1996; Goulet \& Huber, 1993; McAlpine, 1987; Taichi \& Mohamed, 2004; Schuh \& Slater, 1996). Selanjutnya serangga dikelompokkan ke dalam kelompok herbivora, predator, parasitoid, pengurai, ataupun serangga lain. Peranan serangga yang ditemukan didapatkan dari berbagai studi literatur (Rizali et al., 2002; Borror et al., 1996; McAlpine, 1987; Baliadi et al., 2008; Schuh \& Slater, 1996; Taichi \& Mohamed, 2004), dan telah dicocokkan dengan morfospesies yang diperoleh pada waktu pengamatan.
Analisis Data. Data hasil identifikasi serangga ditabulasikan ke database dalam format Excel spreadsheet yang kemudian diinput ke dalam beberapa perangkat lunak. Keseluruhan spesies yang ada diperoleh dari nilai S (observasi) dan nilai penduga Jacknife 1 dengan menggunakan perangkat lunak EstimateS versi 9.1.0 (Colwell \& Coddington, 1994; Colwell, 2013).

Data hasil identifikasi diinput ke dalam perangkat lunak SAS versi 9.1.3 pada taraf nyata 5\% untuk memperoleh hasil analisis ragam (ANOVA) faktorfaktor yang mempengaruhi keanekaragaman serangga. Analisis alfa-diversity menggunakan Shanon-Wienner untuk melihat kekayaan dan kemerataan spesies serangga. Untuk mengetahui kemiripan struktur serangga pada petak pengelolaan hama dan varietas yang berbeda adalah dengan membuat matriks berdasarkan indeks ketidakmiripan Bray-Curtis (Clarke, 1993). Uji lanjut analysis of similarity (ANOSIM) dilakukan untuk mendapatkan nilai statistik koefisien perbedaan struktur komunitas serangga pada petak pengelolaan hama dan varietas yang berbeda. Hasil matriks tersebut dibuat ordinasi dendogram dan non metric multidimensional scaling (MDS) untuk mendapatkan tampilan perbedaan antara struktur komunitas serangga pada pengelolaan hama dan varietas yang berbeda. Analisis tersebut dilakukan dengan menggunakan software $R$ Statistic paket vegan (R Development Core Team, 2012).

\section{HASIL DAN PEMBAHASAN}

Kelimpahan dan Kekayaan Spesies Serangga. Hasil pengambilan sampel serangga dan Collembola pada varietas Anjasmoro dan Wilis pada semua plot perlakuan selama sepuluh kali pengamatan didapatkan 14 ordo serangga dan satu ordo Collembola dengan total individu sebanyak 368.775 dari 122 famili, 539 morfospesies. Berdasarkan hasil perhitungan akumulasi spesies terlihat bahwa semua kurva akumulasi spesies belum mencapai asimtot sampling. Hal ini menunjukkan belum optimalnya jumlah spesies serangga yang ditemukan pada masingmasing plot PHT, P-NK, P-K, dan Kontrol (Gambar 1). Jumlah spesies yang terkumpul jika dibandingkan dengan Jacknife-1 estimator pada varietas Anjasmoro dan Wilis berkisar antara 74,24\% sampai 77,03\% (Tabel 1). Belum optimalnya jumlah spesies yang ditemukan diduga karena keberadaan serangga yang sangat tergantung pada iklim mikrohabitatnya sehingga keanekaragaman jumlah spesies yang terdapat pada setiap titik contoh ulangan terus meningkat seiring bertambahnya jumlah petak contoh. Chao et al. (2009) menyatakan bahwa tidak optimalnya pengambilan sampel serangga umum terjadi pada penelitian ekologis di daerah tropis. 

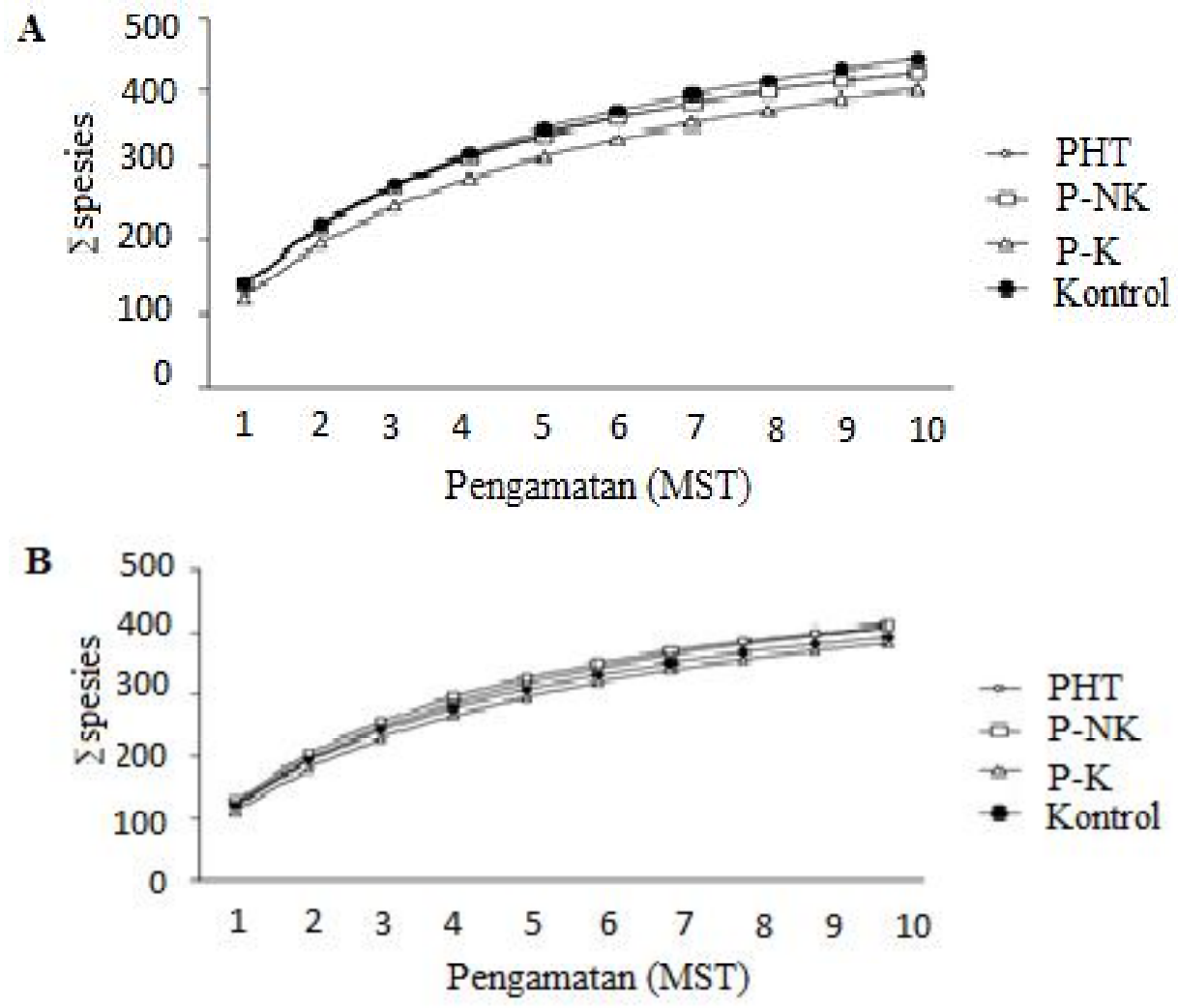

Gambar 1. Kurva akumulasi spesies pada varietas (A) Anjasmoro dan (B) Wilis pada masing-masing petak pengelolaan hama

Tabel 1. Total ordo $(\mathrm{O})$, famili $(\mathrm{F})$, spesies $(\mathrm{S})$, individu $(\mathrm{N})$, indeks keanekaragaman Shannon Wienner $\left(\mathrm{H}^{\prime}\right)$, sebaran (E), dan pendugaan spesies (Jack-1) pada varietas Anjasmoro dan Wilis dengan pengelolaan hama berbeda

\begin{tabular}{|c|c|c|c|c|c|c|}
\hline \multirow{2}{*}{ Varietas } & \multirow{2}{*}{ Total } & \multicolumn{4}{|c|}{ Pengelolaan Hama ${ }^{1}$} & \multirow{2}{*}{ Beda nyata ${ }^{2}$} \\
\hline & & PHT & P-NK & $\mathrm{P}-\mathrm{K}$ & $\overline{\text { Kontrol }}$ & \\
\hline \multirow{7}{*}{ Anjasmoro } & $\mathrm{O}$ & 14 & 14 & 11 & 12 & \multirow{7}{*}{$\begin{array}{l}\left(\mathrm{H}^{\prime}\right) P \text { varietas }=0,84 ; \\
P \text { pengelolaan hama }= \\
0,30\end{array}$} \\
\hline & $\mathrm{F}$ & 108 & 106 & 96 & 106 & \\
\hline & $\mathrm{S}$ & 425 & 425 & 403 & 443 & \\
\hline & $\mathrm{N}$ & 46381 & 45754 & 44449 & 49895 & \\
\hline & $\mathrm{H}^{\prime}$ & 3,10 & 3,26 & 3,13 & 3,22 & \\
\hline & E & 0,51 & 0,54 & 0,52 & 0,53 & \\
\hline & Jack-1 & $77,03 \%$ & $76,71 \%$ & $74,61 \%$ & $75,59 \%$ & \\
\hline \multirow[t]{7}{*}{ Wilis } & $\mathrm{O}$ & 13 & 11 & 14 & 12 & \multirow{7}{*}{$\begin{array}{l}(\mathrm{E}) P \text { varietas }=0,01 ; \\
P \text { pengelolaan hama }= \\
0,90\end{array}$} \\
\hline & $\mathrm{F}$ & 101 & 96 & 94 & 94 & \\
\hline & S & 408 & 409 & 381 & 392 & \\
\hline & $\mathrm{N}$ & 41812 & 43956 & 43058 & 53470 & \\
\hline & $\mathrm{H}^{\prime}$ & 3,17 & 3,13 & 3,13 & 3,19 & \\
\hline & $\mathrm{E}$ & 0,53 & 0,55 & 0,53 & 0,53 & \\
\hline & Jack-1 & $74,53 \%$ & $75,89 \%$ & $74,24 \%$ & $75,03 \%$ & \\
\hline
\end{tabular}

${ }^{1}$ PHT: Pengelolaan Hama Terpadu, P-NK: Pengendalian Non-Kimiawi, P-K: Pengendalian Kimiawi, dan Kontrol; ${ }^{2}$ Beda nyata antar varietas Anjasmoro dan Wilis dan beda nyata antar pengelolaan hama pada pertanaman kedelai pada uji ANOVA $\alpha=0,01$. 
Pada varietas Anjasmoro, jumlah total spesies yang paling banyak ditemukan pada petak kontrol (443) dan paling sedikit ditemukan adalah petak P-K (403). Pada varietas Wilis jumlah total spesies paling banyak pada P-NK (409) dan paling sedikit pada P-K (381). Indeks keanekaragaman spesies berdasarkan ShannonWienner tidak menunjukkan perbedaan antar varietas $(P=0,84)$ dan pengelolaan hama $(P=0,30)$. Indeks kemerataan menunjukkan berbeda signifikan antar varietas $(P=0,01)$ namun tidak berbeda signifikan antar pengelolaan hama $(P=0,90)$ (Tabel 1). Hal ini berbeda dengan penelitian Ristyadi (2011) yang membuktikan bahwa efek penggunaan pestisida terhadap struktur komunitas Artropoda pada pertanaman kedelai hanya berdampak signifikan pada kelimpahan Artropoda tetapi tidak berbeda signifikan terhadap kekayaan spesies. Hillebrand et al. (2008) yang menyatakan bahwa kelimpahan relatif spesies dan kekayaan spesies mempunyai rentang yang hampir sama akibat dari dampak ekologi yang ditentukan dari perbedaan kesehatan ekosistem, meskipun efek dari kemerataan spesies pada ekologi sering mendapat sedikit perhatian.

\section{Komposisi Serangga pada Tanaman Kedelai.} Varietas tanaman yang digunakan berpengaruh signifikan terhadap komposisi serangga herbivora dan serangga bermanfaat pada pertanaman kedelai (ANOSIM statistik serangga herbivora: $\mathrm{R}=1 ; P=0,02$ dan ANOSIM statistik serangga bermanfaat: $\mathrm{R}=0,78 ; P=$ 0,02). Dengan melihat MDS tampak bahwa semakin dekat titik menunjukkan kemiripan komposisi serangga penyusunnya. Distribusi titik MDS serangga herbivora pada masing-masing varietas menunjukkan kecenderungan jarak yang berdekatan, yang berarti komposisi serangga pada semua perlakuan pengelolaan hama pada varietas tersebut relatif lebih mirip dibandingkan dengan komposisi serangga pada varietas lain (Gambar 2a). Pola distribusi komposisi serangga antar pengelolaan hama pada kedua varietas tersebut tidak menunjukkan pola tertentu. Hal ini diduga penyemprotan yang dilakukan kurang berpengaruh terhadap serangga herbivora, dapat disebabkan oleh resistennya serangga herbivora terhadap pestisida atau kurang efektif penggunaan pestisida yang digunakan. Perbedaan komposisi serangga herbivora antar varietas Anjasmoro dan Wilis diduga disebabkan oleh perbedaan arsitektur tanaman pada masing-masing varietas sehingga mempengaruhi mikroiklim yang dibutuhkan oleh serangga herbivora. Selain itu preferensi makan serangga herbivora tertentu diduga juga berbeda.

Komposisi serangga bermanfaat pada perlakuan P-K memperlihatkan jarak yang relatif lebih jauh dibandingkan dengan komposisi serangga pada perlakuan lain di dalam varietas yang sama (Gambar 2b). Hal ini diduga oleh penggunaan pestisida sintetik dengan bahan aktif tertentu yang akan berpengaruh terhadap komposisi serangga bermanfaat. Serangga bermanfaat pada perlakuan PHT, P-NK, dan Kontrol pada varietas Anjasmoro memperlihatkan komposisi yang lebih mirip dibandingkan pada perlakuan P-K. Pada perbandingan kedua varietas komposisi serangga pada perlakuan PHT, P-NK, dan Kontrol pada varietas Wilis lebih tinggi daripada Anjasmoro. Hal ini diduga karena serangga bermanfaat yang berupa parasitoid dan predator keberadaannya dipengaruhi oleh trofik dibawahnya yaitu serangga herbivora. Hal ini sesuai dengan penelitian

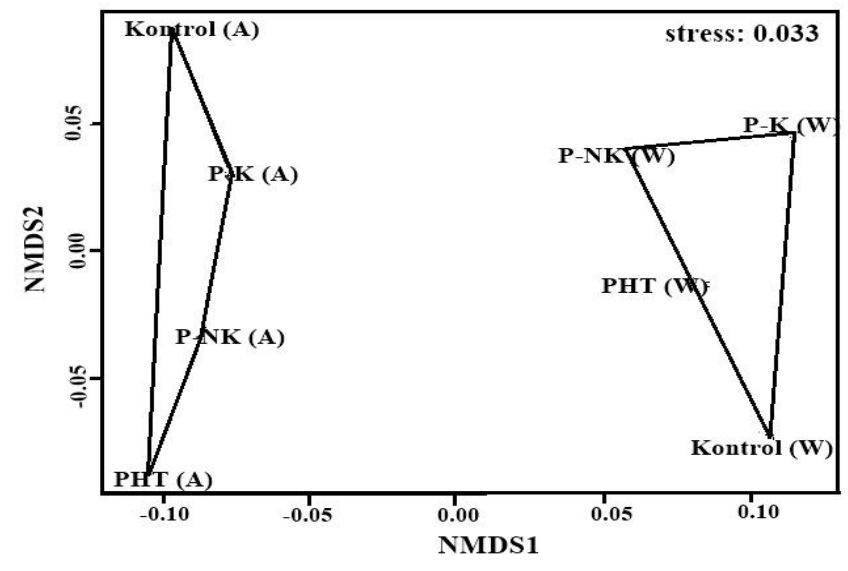

a

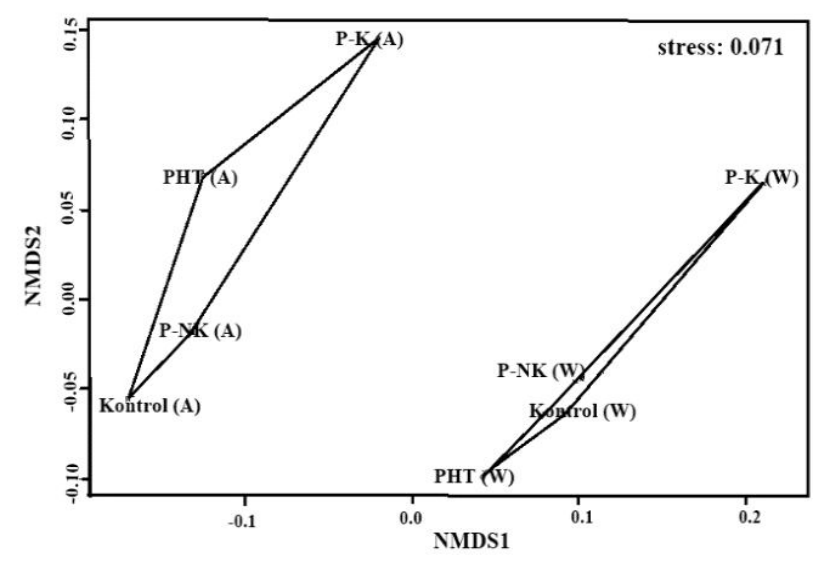

b

Gambar 2. Non metric multi dimensional scaling (MDS) (a) serangga herbivora dan (b) serangga bermanfaat (parasitoid dan predator) berdasarkan indeks Bray-Curtis pada masing-masing pola pengelolaan hama pada varietas Anjasmoro (A) dan Wilis (W). Transformasi: Log (x+1) 
(Okada et al., 1988) bahwa keberadaan serangga bermanfaat dipengaruhi oleh inang atau mangsa yang ada pada pertanaman tersebut.

Untuk mengetahui faktor yang berpengaruh terhadap komposisi serangga pada varietas Anjasmoro dan Wilis dilakukan analisis Simper khusus serangga bermanfaat (parasitoid dan predator) serta herbivora. Hasil analisis Simper menunjukkan bahwa pengaruh komposisi serangga paling besar pada serangga bermanfaat adalah Phoridae sp.13 (Diptera) dan Encyrtidae sp.03 (Hymenoptera) selain itu pengaruh komposisi serangga herbivora paling besar yaitu Bemicia tabaci (Hemiptera : Aleyrodidae) dan Empoasca sp. (Hemiptera: Cicadellidae) (Tabel 2). Hal yang menarik adalah bahwa banyak ditemukannya larva ngengat Caloptilia sp. (Lepidoptera: Gracillariidae) dan kumbang Lema sp. (Coleoptera: Chrysomelidae) selama pengamatan. Spesies tersebut belum pernah dilaporkan sebagai hama pada pertanaman kedelai.

\section{Peranan Fungsional dan Profil Komunitas Serangga Berdasarkan Pengelolaan Hama dan} Varietas Berbeda. Dalam penelitian ini diketahui bahwa serangga yang berasosiasi dengan tanaman kedelai tercatat 539 morfospesies, 192 diantaranya sebagai herbivora, 83 sebagai pengurai, 69 predator, 162 serangga parasitoid, 1 penyerbuk, dan 32 serangga lain yang belum diketahui peranannya (Gambar 3). Pada ekosistem pertanian padi sawah berdasarkan Rizali et al. (2002) didapatkan 435 spesies sedangkan pada penelitian Settle et al. (1996) didapatkan 765 spesies. Pada penelitian ini, banyaknya spesies yang ditemukan pada ekosistem pertanian membuktikan bahwa kekayaan spesies pada ekosistem pertanian kompleks dimana serangga didalamnya mempunyai kontribusi masing-masing dalam ekosistem tersebut. Banyak hal yang mempengaruhi perbedaan kelimpahan dan jenis serangga yang ditemukan, menurut Altieri \& Nicholls (2004) biodiversitas di agroekosistem tergantung dari empat karakteristik: diversitas vegetasi di sekitar agroekosistem, diversitas tanaman budidaya di agroekosistem, intensitas manajemen lahan, dan isolasi agroekosistem dari vegetasi alami.

Pada kedua varietas kedelai, serangga herbivora lebih tinggi pada Kontrol (tanpa pengendalian) dan rendah pada perlakuan PHT namun tidak terlihat adanya perbedaan signifikan antar petak perlakuan (Gambar 4a, 4b). Secara keseluruhan, serangga herbivora puncak populasi yaitu antara 56-63 HST. Tanaman kedelai sekitar umur 56-63 HST adalah masa pertumbuhan polong dan biji dimana pertumbuhan vegetatif daun sudah optimal, diduga pertambahan jenis hama pada fase tersebut diiringi dengan kelimpahannya yang tinggi. Kelimpahan Empoasca sp. ditemukan paling tinggi dan melimpah baik pada fase vegetatif maupun generatif di setiap perlakuan. Pada fase generatif selain Empoasca sp. ditemukan Caloptilia sp. dan B. tabaci dengan kelimpahan tinggi. Hasil penelitian serupa oleh Letourneau \& Bruggen (2001) yang membuktikan bahwa tidak ada perbedaan signifikan pada kerusakan yang diakibatkan oleh hama (pest damage) antara pertanian organik dan konvensional dan kelimpahan ratarata herbivora hampir sama. Penelitian Settle et al. (1996) menyatakan bahwa pada pertanaman padi dengan tanpa penyemprotan didapatkan kelimpahan spesies serangga herbivora yang lebih rendah daripada petak dengan penyemprotan insektisida sintetik, pada petak dengan penyemprotan insektisida sintetik memperlihatkan pola klasik dari resurgensi insektisida.

Populasi pengurai tertinggi ada pada awal musim tanam 7-14 HST setelah itu populasinya relatif stabil sepanjang musim tanam (Gambar 4c, 4d). Pada semua petak perlakuan pada fase vegetatif, spesies Isotoma sp., Isotomurus sp., dan Pseudosinella sp. ditemukan tinggi. Tingginya pengurai tersebut didukung dengan tingginya curah hujan pada awal musim tanam sehingga kelimpahannya pun tinggi. Sedangkan pada fase generatif kelimpahan Pseudosinella sp. dan Valenzuela sp. tinggi.

Pada kedua varietas kedelai, kelimpahan serangga parasitoid pada Kontrol dan P-NK dimana tanpa pestisida cenderung lebih tinggi daripada PHT dan P-K yang mempergunakan pestisida kimia (Gambar 4e, 4f). Pada setiap perlakuan, kelimpahan tinggi parasitoid pada fase vegetatif yaitu Conopidae sp.01 dan Megaselia spp. sedangkan pada fase generatif spesies dari famili Encyrtidae ditemukan dengan kelimpahan tinggi. Crowder et al. (2010) menyatakan bahwa pola pengendalian non-konvensional dengan atau tanpa biopestisida, akan meningkatkan kelimpahan relatif spesies (evenness) dari musuh alami dan berpotensi menekan populasi hama. Minimumnya penggunaan pestisida sintetik pada pengendalian non-konvensional akan memberikan kesempatan kepada artropoda lain untuk dapat bersaing dalam sistem.

Pada kedua varietas kedelai, populasi predator cenderung rendah dan meningkat di akhir musim tanam (Gambar 4g, 4h). Peningkatan populasi predator di akhir musim tanam ini dinilai tidak efektif karena predator berkembang terlambat dan populasinya jauh lebih rendah daripada herbivora. Pada setiap perlakuan, kelimpahan tinggi predator pada fase vegetatif yaitu Taxorhynchites spp. Spesies tersebut pada fase generatif kelimpahannya jauh lebih tinggi lagi dibandingkan pada fase vegetatif. 
Tabel 2. Hasil Uji Simper serangga herbivora dan serangga bermanfat pada varietas Anjasmoro dan Wilis

\begin{tabular}{ccl}
\hline No & Spesies Serangga Bermanfaat & Spesies Serangga Herbivora \\
\hline 1 & Phoridae sp.13 13.03 & Bemicia tabaci \\
2 & Encyrtidae sp.03 & Empoasca \\
3 & Phoridae sp.06 & Thrips parvispinus \\
4 & Encyrtidae sp.01 & Thripidae sp.01 \\
5 & Conopidae sp.01 & Megalurothrips $\mathrm{sp} .01$ \\
6 & Cryptochetum sp.04 & Melanothrips $\mathrm{sp} .02$ \\
7 & Taxorhynchites sp.03 & Cicadula \\
8 & Taxorhynchites $\mathrm{sp} .01$ & Caloptilia sp. \\
9 & Encyrtidae sp.09 & Chlorops sp.08 \\
10 & Verania & Phlaelothripidae sp.01 \\
11 & Formicidae sp.01 & Lema sp. \\
\hline
\end{tabular}

Ditampilkan dari 11 morfospesies dengan urutan kontribusi paling tinggi.

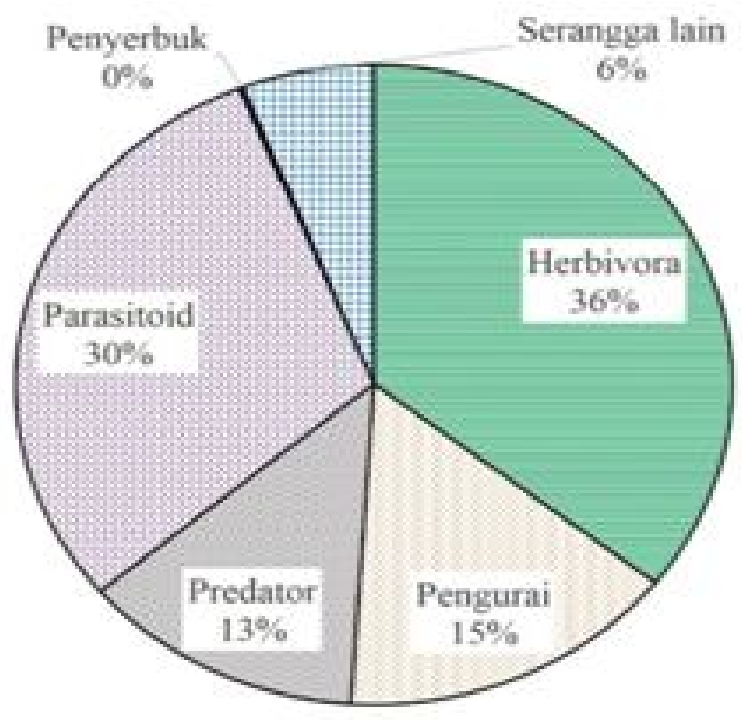

Gambar 3. Persentase peranan fungsional serangga dari spesies yang ditemukan

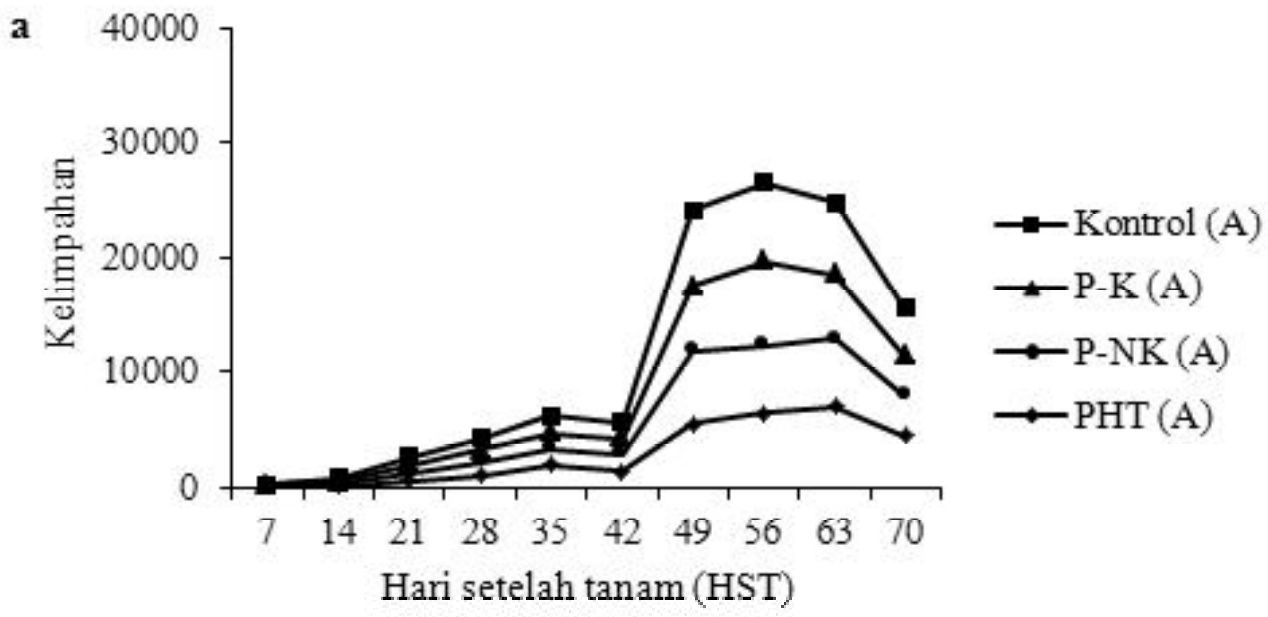




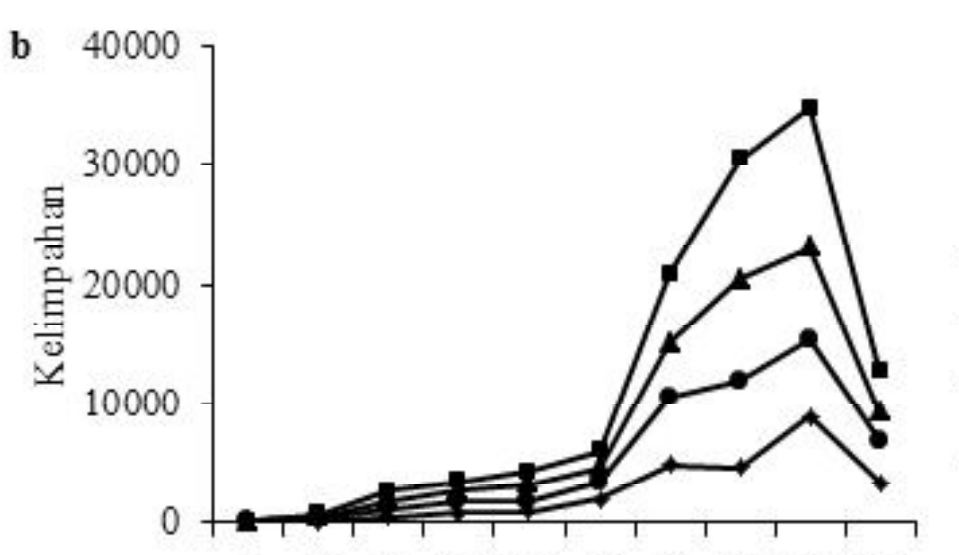

$\begin{array}{llllllllll}7 & 14 & 21 & 28 & 35 & 42 & 49 & 56 & 63 & 70\end{array}$

Hari setelah tanam (HST)
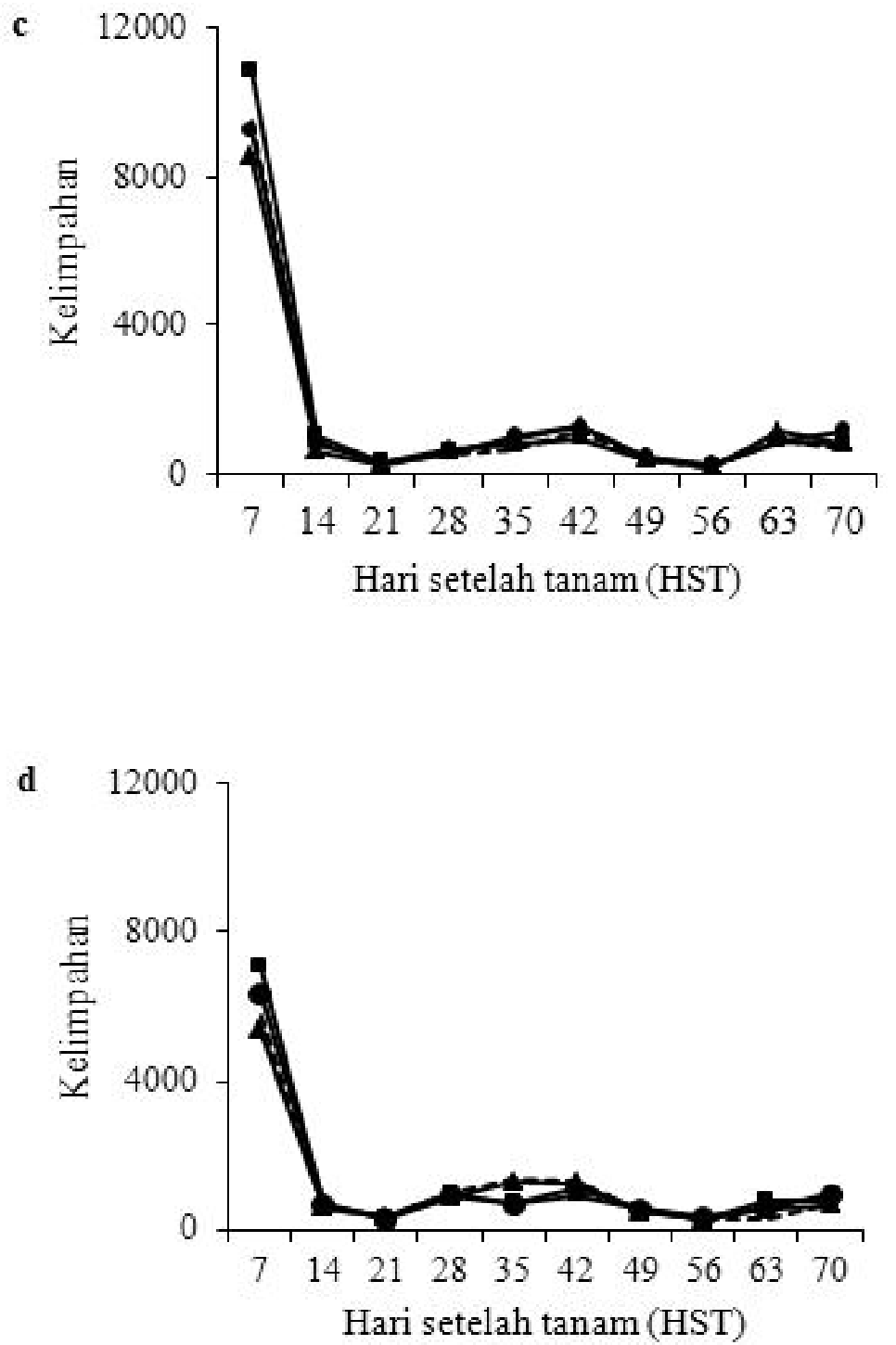

$\rightarrow$ Kontrol (W)

$\rightarrow \mathrm{P}-\mathrm{K}(\mathrm{W})$

$\rightarrow$ P-NK (W)

$\rightarrow$ PHT (W)

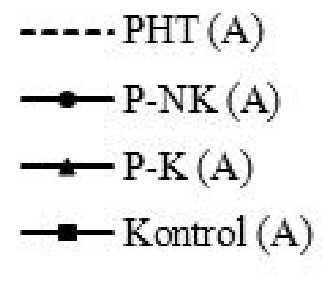

---PHT (W)

$\multimap$ P-NK (W)

$\longrightarrow \mathrm{P}-\mathrm{K}(\mathrm{W})$

$\longrightarrow$ Kontrol (W) 

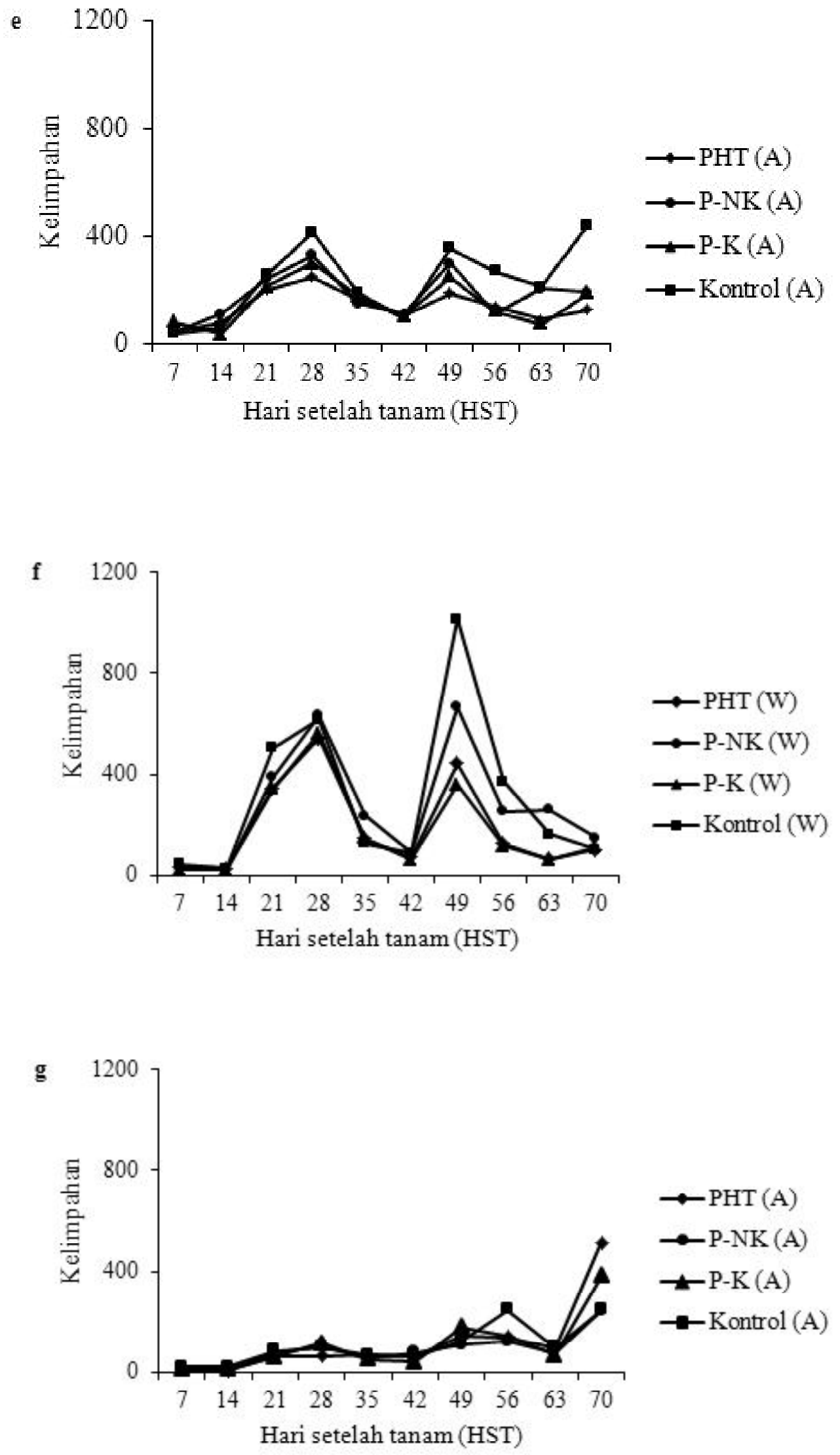


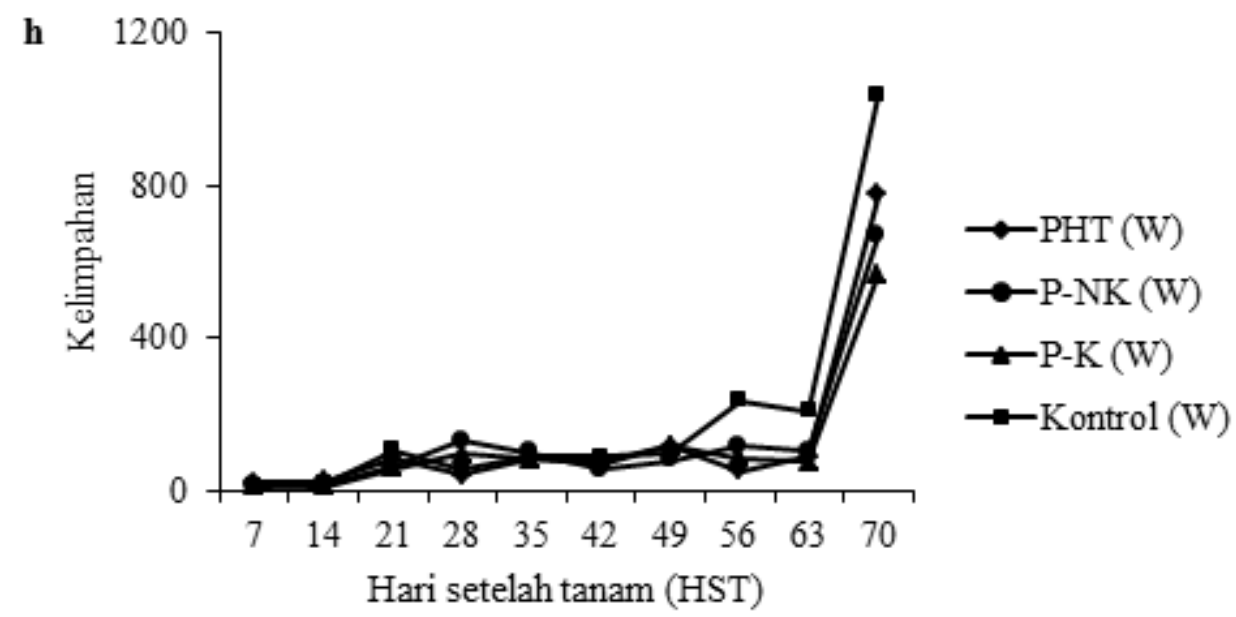

Gambar 4. Profil komunitas serangga herbivora (a-b), pengurai (c-d), parasitoid (e-f), dan predator (g-h) pada perlakuan pengelolaan hama berbeda pada varietas Anjasmoro (A) dan Wilis (W)

\section{SIMPULAN}

Serangga yang tertangkap dalam pengamatan sebanyak 368.775 individu yang terdiri dari 14 ordo, 122 famili dan 539 morfospesies. Berdasarkan fungsi ekologi, serangga yang didapatkan terdiri dari 192 spesies sebagai herbivora, 83 sebagai pengurai, 1 sebagai penyerbuk, 69 predator, 162 serangga parasitoid, dan 32 serangga belum diketahui peranannya. Perlakuan varietas dan pengelolaan hama tidak berpengaruh signifikan terhadap indeks keanekaragaman serangga. Komposisi serangga herbivora dan serangga bermanfaat di pertanaman kedelai memiliki perbedaan komposisi

\section{DAFTAR PUSTAKA}

Altieri MA \& Nicholls CI. 2004. Biodiversity and Pest Management in Agroecosystems. Second Edition. Food Products Press. Binghamton (NY).

Arifin M. 2012. Bioinsektisida SlNPV untuk mengendalikan ulat grayak mendukung swasembada kedelai. Pengembangan Inovasi Pertanian 5(1): 19-31.

Baliadi Y \& Tengkano W. 2010. Lalat pengorok daun, Liriomyza sp. (Diptera: Agromyzidae), hama baru pada tanaman kedelai di Indonesia. J. Litbang Pert. 29(1): 1-9.
Baliadi Y, Tengkano W, Suharsono, \& Bedjo. 2008. Pedoman Rekomendasi Pengelolaan Hama Terpadu (PHT) Tanaman Kedelai di Indonesia. Malang, Balai Penelitian Tanaman Kacang-kacangan dan Umbi-umbian.

Borror DJ, Triplehorn CA, \& Jhonson NF. 1996. Pengenalan Pelajaran Serangga. Edisi ke-6. Penerjemah: Partosoedjono S. Gadjah Mada University Press. Yogyakarta.

Chao A, Colwell RK, Lin CW, \& Gotelli NJ. 2009. Sufficient sampling for asymptotic minimum species richness estimators. Ecology 90(4): 1125-1133.

Clarke KR. 1993. Non-parametric multivariate analyses of change in community structure. Aust. J. Ecol. 18(1): 117-143.

Colwell RK \& Coddington JA. 1994. Estimating terrestrial biodiversity through extrapolation. Phil. Trans. R. Soc. Lon. B. 345(1311): 101-118.

Colwell RK. 2013. EstimateS: Statistical Estimation of Species Richness and Shared Species from Samples [internet]. http://viceroy.eeb.uconn.edu/ estimates/. Diunduh tanggal 11 November 2013.

Crowder DW, Northfield TD, Strand MR, \& Snyder WE. 2010. Organic agriculture promotes evenness and natural pest control. Nature. 466(7302):109-120. 
[CSIRO] Commonwealth Scientific and Industrial Research Organization. 1991. The Insect of Australia: a Textbook for Students and Research Workers. Second edition. Melbourne University Publishing. Victoria.

Ghulamahdi M, Melati M, \& Sagala D. 2009. Production of soybean varieties under saturated soil culture on tidal swamps. J. Agron. Indones. 37(3): 226232.

Goulet H \& Huber JT. 1993. Hymenoptera of the World: an Identification Guide to Families. Research Branch Agriculture Canada. Ottawa (CA).

Hillebrand H, Bennett DM, \& Cadotte MW. 2008. Consequences of dominance: a review of evenness effects on local and regional ecosystem processes. Ecology 89(6): 1510-1520.

Letourneau D \& Bruggen A. 2006. Crop protection in organic agriculture. In: Kristiansen P, Taji A, \& Reganold J. (Eds.) pp.93-121 Organic Agriculture, A Global Perspective. Collingwood, Victoria: CSIRO publishing.

McAlpine JF. 1987. Manual of Nearctic Diptera Volume 2. Research Branch Agriculture Canada. Ottawa (CA).

Okada T, Tengkano W, \& Djuwarso T. 1988. An outline of soybean pest in Indonesia in faunistic aspects. Seminar of Bogor Research Institute for Food Crops. pp. 37. Bogor Core Team. December 6, 1988.

R Development CT. 2013. R: a Language and Environment for Statistical Computing. R Foundation for Statistical Computing. Vienna. http://cran.r-project.org/. Diakses tanggal 16 November 2013.
Ristyadi D. 2011. Influence of pesticide type and adjacent crop vegetation on arthropod community structure through a soybean/sorghum cropping cycle. Thesis. University of New England. Armidale.

Rizali A, Buchori D, \& Triwidodo H. 2002. Keanekaragaman serangga pada lahan persawahan tepian hutan: indikator untuk kesehatan lingkungan. Hayati 9(2): 41-48.

Schuh RT \& Slater JA. 1996. True Bugs of the World (Hemiptera:Heteroptera) Classification and Natural History. Cornell University Press. New York.

Settle WH, Ariawan H, Astuti ET, Cahyana W, Hakim AL, Hindayana D, \& Lestari AS. 1996. Managing tropical rice pests through conservation of generalist natural enemies and alternative prey. Ecology 77(7): 1975-1988.

Tahir AG, Darwanto DH, Mulyo JH, \& Jamhari. 2011. Analisis risiko produksi usahatani kedelai berbagai tipe lahan di Sulawesi Selatan. J. Sos. Eko. Pertanian 8(1): 1-15.

Taichi T \& Mohamed M. 2004. Identification Key to the Families in Diptera (Insecta). Japan International Cooperation Agency. Universiti Malaysia Sabah. Malaysia.

Tillman PG. 2014. Physical barriers for suppression of movement of adult stink bugs into cotton. J. Pest Sci. 87(3): 419-427. 